\title{
Missionale kerkwees en die elektroniese sosiale media
}

\author{
Authors: \\ Martin J. Lazenby ${ }^{1}$ \\ Cornelius J.P. Niemandt ${ }^{1}$ \\ Affiliations: \\ ${ }^{1}$ Department of Theology, \\ University of Pretoria, \\ South Africa \\ Correspondence to: \\ Martin Lazenby \\ Email: \\ doklazenby@gmail.com \\ Postal address: \\ Private Bag X20, Pretoria \\ 0028, South Africa \\ Dates: \\ Received: 16 Oct. 2013 \\ Accepted: 14 Mar. 2014 \\ Published: 07 Nov. 2014 \\ How to cite this article: \\ Lazenby, M.J. \& Niemandt, \\ C.J.P., 2014, 'Missionale \\ kerkwees en die elektroniese \\ sosiale media', In die Skriflig \\ 48(1), Art. \#1770, 6 pages. \\ http://dx.doi.org/10.4102/ \\ ids.v48i1.1770

\section{Copyright:} \\ (C) 2014. The Authors. \\ Licensee: AOSIS \\ OpenJournals. This work \\ is licensed under the \\ Creative Commons \\ Attribution License.
}

Die geweldige toename in die benutting van die sosiale media as interaktiewe kommunikasiemiddel wêreldwyd, bied aan die Christelike kerk groot missionale geleenthede, maar stel ook groot uitdagings en eise. Hierdie geleentheid moet benut word om missionaal 'n verskil ten gunste van God se koninkryk te maak. Die inhoud en die kommunikasiestyl kom onder die vergrootglas. Hierdie artikel poog om 'n paar bybels-etiese beginsels aan te dui wat as basis vir die missionale styl van kommunikasie moet dien. As uitgangspunt word die Bybel as die Woord van God gebruik. Daar word geredeneer dat die moreel-etiese beginsels wat in die Bybel aan die gelowige voorgeskryf word, van die grootste belang is om gestalte te gee aan die koninkryk van God in hierdie wêreld wanneer via die sosiale media op horisontale vlak met mense gekommunikeer word. Dit gaan dus vir die gelowige nooit net om humanistiese, sosiale kommunikasie nie, maar altyd dat die beeld van God in hierdie wêreld geëer en sy koninkryk daardeur uitgebou word. Vir die Christen-gelowige gaan dit nooit om die mens nie, maar altyd om God se eer en die manifestasie van sy koninkryk.

Being a missional church and the social media. The tremendous increase in using the social media as interactive communication medium worldwide creates the opportunity for the Christian church to make a missional difference in favour of God's kingdom on earth. It also brings great challenges with it. This means that the way communication via the mass social media is done, becomes of the utmost importance. The content as well as the manner in which the communication is conducted must be considered. This article aims at providing certain basic biblical-ethical principles for communicating in the mass social media that will serve the missional calling of the church. The point of departure is the Word of God. The basic focus of the argument is that the moral-ethical principles given to the believer in the Bible are of the utmost importance to give practical form to the kingdom of God on earth by means of horisontal communication via the social media. For the Christian believer the focus never falls on humanistic social communication as such, but always to glorify the image of God and thereby expand God's kingdom in this world.

\section{Inleiding}

Die doel van God se skepping hou verband met die verheerliking van God deurdat Hy as die Koning en Heerser oor alles erkenning sal geniet (vgl. Matt 6:33; Rom 11:37; Kol 1:16).

Hierdie verheerliking van God gebeur hoofsaaklik op twee maniere, naamlik deur mense wat God in die geloof as hulle God erken en op verskillende wyses sy heerlikheid bekendmaak, maar ook deur mense wat God nie as God aanvaar nie, maar tog aan God erkenning gee en sy eer bevorder, al is dit selfs tot hulle eie nadeel. ' $n$ Voorbeeld hiervan is die reaksie van koning Nebukadnesar van Babel toe die vriende van Daniël, Sadrag, Mesag en Abednego, lewend en ongeskonde uit die brandende vuuroond gestap het (Dan 3:28-29; Lazenby 2013:33).

N.T. Wright (2012:176) beskou die wêreld (heaven and earth) as God se tempel '... and his imagebearers are the key elements in that temple'. 'n Mens sou ook kon praat van die bekendmaking van God se missionale plan vir die wêreld. Heel eenvoudig gestel, sou 'n mens kon sê dat dit in hierdie missionale plan gaan om '... the over-arching dimension of Christian life in the world' (Saayman 2007:5). Bosch maak 'n veelseggende opmerking wanneer hy by Gunther en Hoekendijk aansluit en sê dat God se liefde en aandag primêr op die wêreld gerig is (vgl. Joh 3:16) en sending die deelname aan God se bestaan in die wêreld is (Bosch 1991:10).

God gebruik vir hierdie doel mense. Wright (2006) sê:

The reason why we know we should be doing mission, the basis, foundation or grounds on which we justify it, must be found in the Bible. The Bible renders to us the story of God's mission through God's 
people in their engagement with God's world for the sake of the whole of God's creation.

Mission is not just one of a list of things that the Bible happens to talk about, only a bit more urgency than some. Mission is, in that much-abused phrase, 'what it's all about'. (p. 21-22)

Volgens Wright begin hierdie missionale opdrag by die verbondsluiting in Genesis 12:2 en met die uitspreek van God se seën oor Abraham kom ook die eerste groot sendingopdrag, naamlik 'Ek sal jou seën en jou 'n man van groot betekenis maak, en jy moet tot 'n seën wees'. In die Nuwe Testament realiseer die koninkryk van God in die koms van Jesus Christus na die aarde. Na Jesus se hemelvaart word die missionale verantwoordelikheid aan Jesus se kerk toegesê: 'Gaan dan na al die nasies toe en maak die mense my dissipels: doop hulle in die Naam van die Vader en die Seun en die Heilige Gees' (Matt 28:19; vgl Luk 21:48).

Hierdie missionale opdrag moet in die konteks van die tyd uitgevoer word. Die konteks neem verskillende inhoude aan na gelang van die omstandighede en die tyd wat ter sake is. In hierdie artikel word spesifiek na die konteks van die elektroniese sosiale media verwys waarin gelowiges hulle missionale roeping gestand moet doen. Die optrede van gelowiges wat by God se werk aansluit, het altyd 'n sterk etiese karakter en inhoud. Hierdie optrede van die gelowiges sluit ook kommunikasie in. Kommunikasie deur middel van elektroniese sosiale media tussen mense dwarsoor die hele wêreld oor grense heen, is 'n realiteit wat ook aan die missionale roeping van die Christelike kerk geweldige uitdagings stel. In hierdie artikel word aangetoon hoe belangrik die handhawing van bybelse etiek vir die realisering van hierdie roeping in die sosiale media is. Sending gaan oor die morele en etiese transformasie van God se mense om volgens God se wil te leef. God se sending word gedien waar daar gemeenskappe is wat volgens die wil van God lewe (Wright 2010:93). Gelowiges moet sodanig lewe dat hulle daardeur duidelik kommunikeer dat hulle identiteit in Christus tot eer van God is (vgl. Kok 2011).

Met sosiale media word hier na 'n hele verskeidenheid interaktiewe digitale kommunikasievorms verwys. Kaplan en Haenlein (2010:59) verwys daarna as 'a group of Internetbased applications that build on the ideological and technological foundations of Web 2.0 and that allow the creation and exchange of user-generated content'. Dit is ' $\mathrm{n}$ vorm van horisontale kommunikasie waar die inhoud gegenereer en daarop kommentaar gelewer word deur 'amateurs, by the crowds of users rather than a few professionals' (Challies 2011:loc. 1117). Dit bied aan mense die geleentheid om met mekaar te kommunikeer sonder om deur die amptelike kanale (wat die reëls vir gemeenskapskommunikasie bepaal), te gaan. Hierdie soort kommunikasie wissel van kort 140-karakter boodskappe (Twitter), die plasing van foto's, video's, klanklêers op die internet, forums en groepgesprekke. Onder die sosiale media wat die meeste gebruik word, is Facebook, Twitter en LinkedIn (vgl. Lazenby 2013 vir 'n meer volledige lys - kyk veral op bl. 99-101).
Daar is heelwat voordele in die benutting van die sosiale media. Die sosiale media is maklik om te gebruik, die koste is baie laag (indien enige), 'n mens kan met mense wat dieselfde as jyself dink, kontak maak, groter gehore kan bereik word, verhoudings kan letterlik wêreldwyd gebou word en 'n groot groep mense kan beïnvloed word sonder dat jy naby hulle kom (vgl. Brown 2011:loc. 22; Kaplan \& Haenlein 2010:59-68). Baie besighede benut dus hierdie media om hulle saak te bemark (vgl. Hille 2011 en ook Deckers \& Lacy 2010).

Challies (2011) sê dat 'n mens deur die internet dit regkry om reg oor die wêreld nuwe vriendskappe te sluit wat 'n kosbare invloed op jou lewe het.

This new digital world is a world built on socializing, on communication, and we are finding that social mores are quickly changing so that we declare people we've never met, our friends, and many of us develop our deepest relationships through social networks and games. (p. loc 1088)

\section{Agtergrond en aktualiteit}

Dwarsdeur die Ou Testament, in Jesus se hele aardse bediening en later ook in die bediening van die apostels, word beklemtoon dat die missionale bediening moet geskied deur 'n lewenstyl wat daarby pas (vgl. Jes 58:6-7; Matt 5-7; Kol 3; 1 Pet 3:1-2). Die missionale verantwoordelikheid van Jesus se kerk geld vir die gelowiges se hele lewe, ook wanneer hulle in ' $n$ postmoderne samelewing die sosiale media benut om met ander te kommunikeer. Die vraag is verder watter impak die missionale karakter van kerkwees op die kommunikasie via die internet het. Dit hang saam met die mens se basiese behoefte om iewers tuis te kom en te behoort. Rice (2009) stel dit soos volg:

The kind of connection we're longing for - whether consciously or unconsciously - is the kind that creates a sense of belonging within us, a sense that we are 'safe, cared for, protected, and loved'. (p. 174)

Juis omdat hierdie onderlinge betrokkenheid by mekaar waar is, is die mens ook aan positiewe en negatiewe beïnvloeding deur die sosiale media blootgestel. Dit is baie nodig om oor die etiek van die internet te praat vanweë die feit dat die internet ook deel vorm van die gebroke werklikheid waarin ons leef en dat sondige mense dit misbruik om hulle eie kwade bedoelings te bevorder. ${ }^{1}$ Die grootste bedreiging kom van gemorspos wat deur middel van e-posboodskappe na rekenaars gestuur word. 'n Organisasie soos M86 Security Labs (2012) vermeld in sy jongste verslag dat $72.1 \%$ van inkomende e-posse van firmas onder hulle beskerming deur gemorspos geïnfekteer was. Die gevaar van gemorspos is dat dit kwaadwillige virusse op rekenaars aflaai wat op verskillende maniere jou data infiltreer en vernietig. ' $n$ Firma soos Spamhaus bied interessante statistiek oor die oorsprong van hierdie gemorspos. Die VSA staan bo-aan die lys gevolg deur Sjina en Rusland (Spamhaus 2012).

Behalwe die gevaar van virusbesmetting is daar ook talle ander misbruike wat via die internet 'n negatiewe invloed

1.Met kwade bedoelingsword enige elektroniese kommunikasie bedoel wat die privaatheid van mense of firmas bedreig of wat daarop gerig is om ' $n$ nadelige effek tot gevolg te hê. 
op mense uitoefen. Lazenby (2013:103) sê byvoorbeeld: 'Dink maar net aan die promovering van pornografie wat vrylik beskikbaar is, geweld, negatiewe taalgebruik en so sal die lysie nog langer gemaak kan word.'

Miljoene mense word letterlik daagliks deur gemorspos beïnvloed. Kwaadwillige boodskappe beloop daagliks 14.5 biljoen. Sommige maatskappye beweer dat kwaadwillige boodskappe selfs daaagliks soveel as $73 \%$ van alle e-pos uitmaak (vgl Spamlaws 2012).

Die media as sodanig hou nie 'n bedreiging in nie, maar die probleem is dat dit mense in 'n gebroke werklikheid is wat kommunikeer. In hierdie verband het die Christen 'n spesiale verantwoordelikheid. In hierdie verband skryf Stanley (2011):

As a Christian, you have the unique challenge of simultaneously living in two worlds. You live in this natural world, where you have responsibilities to your community and nation. You are also a citizen of the kingdom of God and are accountable to the Lord Almighty (see Philippians 3:20-21). (p. 8)

Ons moet mekaar dus help om 'n stel norme daar te stel waaraan ons gehoorsaam moet wees sodat die sosiale media tot opbou van mense benut kan word en God se koninkryk daardeur uitgebou word. Hoe gelowiges met die wêreld in verbinding tree deur byvoorbeeld Facebook, Twitter en LinkedIn, vorm deel van hulle getuienis oor God. Deur die ignorering van moreel-etiese beginsels kan gelowiges hulle missionale verantwoordelikheid kelder en kan hierdie getuienis 'n negatiewe beeld van God aan die wêreld oordra.

Waarop moet die etiese beginsels berus sodat dit as geldend aanvaar kan word? Miskien vra Feinberg en Feinberg (2010) die regte vraag wanneer hulle poneer:

What makes good acts good and evil acts evil? If Nazi soldiers ask if I am hiding Jews in my attic, is it immoral to lie in order to safeguard those I am protecting? How do I know my moral rules are correct? How would I prove that Christian ethics are binding on non-Christians? (p. 21)

Die laaste deel van sy opmerking is vir ons doel veral belangrik. Morele waardes word altyd vanuit ' $n$ bepaalde kultuur, konteks en godsdienstige agtergrond benader. Vir Christene mag dit miskien ononderhandelbaar lyk dat etiek vanuit 'n Christelike konteks bekyk moet word, maar watter gesag het ons om te beweer dat die beginsels wat vir mense buite die Christelike etiek geformuleer word, wel geldig is? Die verskynsel van pluralisme as postmodernistiese invloed, beweer juis dat waarheid nie absoluut is nie, maar ten nouste met die bepaalde kultuur van gemeenskappe gepaard gaan. Leffel (2012) verduidelik die term pluralisme soos volg: "Pluralists say that truth is a "social construction". It is created through social consensus and tradition, not discovered in reality that exists independently of our beliefs.' Omdat waarheid dus 'n subjektiewe konstruksie is en nie objektief van aard is nie, is dit arrogant van die Christen om iemand van ' $n$ ander kultuur te probeer oorhaal om 'n Christen te word. Daarom word gemeen dat dit diskrimenerend is om die evangelie op ander af te dwing.
Volgens Leffel is dit egter nie die Bybel se bedoeling om te diskrimineer en arrogant te wees nie. Wanneer die evangelie diskriminerend verkondig word, pas dit nie in by die Bybel se bedoeling van liefde nie.

\section{Die Woord van God as uitangspunt}

Omdat dit hier om Christelike waardes gaan, word die Woord van God as die basis vir die gesprek gebruik. Oor die Woord van God word soos volg in artikel 3 van die Nederlandse Geloofsbelydenis geskryf (NGK 1988):

Ons bely dat hierdie Woord van God nie deur die wil van 'n mens gestuur of voortgebring is nie, maar die heilige mense van God het dit, deur die Heilige Gees gedrywe, gespreek, soos die heilige Petrus sê (2 Pet. 1:21). Daarna het God deur sy besondere sorg vir ons en ons saligheid sy knegte (die profete en apostels) beveel om sy geopenbaarde Woord op skrif te stel, en Hy self het met sy vinger die twee tafels van die wet geskrywe. Daarom noem ons sulke geskrifte die heilige en Goddelike Skrif. (bl. 155)

In artikel 5 word daarmee saam soos volg bely: 'Ons aanvaar al hierdie boeke, en hulle alleen, as heilig en kanoniek om ons geloof daarna te rig, daarop te grondves en daarmee te bevestig.' (NGK 1988: 156). Per slot van rekening word in die Bybel self verklaar:

Die woord van God is lewend en kragtig. Dit is skerper as enige swaard met twee snykante en dring deur selfs tot die skeiding van siel en gees en van gewrigte en murg. Dit beoordeel die bedoelings en gedagtes van die hart. Daar is ook niks in die skepping wat vir God onsigbaar is nie; alles lê oop en bloot voor sy oë. En aan Hom moet ons rekenskap gee. (Heb 4:12-13.)

Die bedoeling is nie om 'n lysie van moets en moenies op te stel nie, maar daar moet veral na ' $n$ aantal duidelike beginsels gekyk word. Verskillende persone het al pogings aangewend om 'n lys van beginsels daar te stel. Allan Turner (2012) werk byvoorbeeld met 'n stel van vyf beginsels waaraan Christene se gedrag moet voldoen om aan God se liefdesgebod gehoorsaam te wees en wat binne enige kultuurgroep geldig is:

- Is dit in konflik met enige duidelike onderrig in die Woord van God?

- Veroorsaak dit fisiese, psigiese of spirituele skade aan die mens, die tempel van die Gees?

- Het dit enige nadelige effek op die swakker gelowiges of die nie-gelowiges?

- Onteer dit die uitgesproke wil van enigiemand wat 'n godgegewe reg het om oor my te heers?

- Verheerlik dit God? Mag ek dus God se seën met 'n skoon gewete vra? (vgl Turner 2012).

Die beginsels van bybelse etiek geld vir alle terreine en beroepe waarby Christen-gelowiges betrokke is. Wanneer die Christian Medical Fellowship in Engeland (2012) na etiese beginsels vir die mediese profesie soek, word van die volgende standpunt uitgegaan: 'We should resist the temptation to construct a pharisaïcal list of do's and don'ts but rather look for biblical ethical principles to guide our decision making.' Daarmee word bedoel dat die samevatting van die wet, naamlik om 
God bo alles lief te hê en jou naaste soos jouself (Matt 22:37-40), in alle gedrag en kommunikasie van Christene eerbiedig moet word. Christelike moraliteit gaan verder as die blote wettiese gehoorsaamheid. Dit beteken om die tweede myl saam te stap.

Geisler (2010) beklemtoon die onderskeid tussen twee benaderings van die etiek, naamlik tussen Deontological ethics en Teleological ethics. Die verskil tussen hierdie twee word soos volg in Tabel 1 (loc 164) opgesom.

Wat is eties korrekte gedrag? Feinberg en Feinberg (2010) formuleer dit raak:

To act ethically or morally means to act in accord with accepted rules of conduct that cover moral (as opposed to non-moral) matters. To have ethics or a morality is to hold a set of beliefs about what is good and evil, commanded and forbidden. (p. 21)

Christelike etiek word dus sterk aan sekere gegewe beginsels gebind wat as opdragte bindend vir die gewete van die mens is.

Dit op sigself is nie so 'n maklike saak nie. Die oomblik wanneer oor die Woord van God gepraat word, kom Skrifgebruik ter sprake. Hieroor is uiteenlopende menings onder gelowiges. Daar word egter van die veronderstelling uitgegaan dat Skrifgebruik in ons tyd baie duidelik rekening moet hou met die feit dat die Bybel ' $n$ baie ou geskrif is wat primêr tot stand gekom het in 'n tyd waarvan die konteks radikaal van die konteks van ons tyd verskil het. Claassen en Loubser (2010) merk die volgende op:

Die konteks van 'n teks is kardinaal vir die verstaan daarvan. Dit is veral belangrik in die geval van die lees van 'n Bybelteks. Trouens waar die Bybel ook al misbruik is en allerhande eierdanse rondom die betekenis van 'n teks uitgevoer is, is nie moeite gemaak met die konteks nie. Indien die konteks buite rekening gelaat word, kan die Bybel gebruik word om letterlik enige iets te sê. As daar gepraat word oor die verstaan van tekste moet dit altyd as 'teks-binne-konteks' verstaan word. Elke teks moet in sy eie, anderse en unieke leefkonteks verstaan word. Bybelgedeeltes moet gelees word teen die agtergrond van die historiese, kulturele en sosiopolitieke konteks waarbinne dit ontstaan het. (bl. 6)

Feinberg en Feinberg (2010:40-42) erken dat die Skrif die bron van alle etiese norme moet wees en vra dan of dit hoegenaamd moontlik is dat die Bybel, wat in 'n ander tyd en plek geskryf is as dié waarin ons vandag leef, gebruik kan word as basis van die etiek. Hulle voeg nog 'n verdere vraag hierby, naamlik of die Ou Testament hoegenaamd iets te sê het vir die Christen wat in die Nuwe-Testamentiese tyd ná die koms van Jesus Christus leef. Verder tref die Feinberg broers

TABEL 1: Deontological ethics versus Teolelogical ethics.

\begin{tabular}{ll}
\hline Deontological Ethics & Teleological Ethics \\
\hline Rule determines the result. & Result determines the rule. \\
Rule is the basis of the act. & Result is the basis of the act. \\
Rule is good regardless of result. & Rule is good because of result. \\
Result is always calculated within the rules. & $\begin{array}{l}\text { Result is sometimes used to break } \\
\text { the rules. }\end{array}$ \\
\hline
\end{tabular}

'n belangrike onderskeid tussen bybelse etiek en die gebruik van die Bybel in etiek. Om hierdie probleem te help oplos, bied hulle die volgende stel riglyne aan vir die benutting van die Bybel in etiese sake (vgl. Feinberg\& Feinberg 2010:42):

- Eerstens moet onderskei word tussen algemene beginsels of opdragte en spesifieke toepassings van daardie opdragte. Die kern van hierdie punt is die feit dat algemene beginsels gewoonlik in baie verskillende situasies geld, inbegrepe die konteks van ons eie tyd.

- Die tweede beginsel is die feit dat die Ou sowel as die Nuwe Testament in die eerste plek binne die sosiale, politieke en religieuse konteks van hulle ontstaanstyd geïnterpreteer moet word.

- Indien moontlik moet derdens gepoog word om die rede vir die opdrag vas te stel. Is dit byvoorbeeld teologies of kultureel van aard?

- Vierdens moet op die verband tussen die moderne tyd en die Ou-Testamentiese tyd besluit word

Met bogenoemde as agtergrond, word vervolgens gepoog om die belangrikste beginsels vir die gebruik van die sosiale media as kommunikasiestelsel te bespreek met die oog op 'n missionale bediening.

\section{Die skeppingsmatigheid van die mens}

Die eerste etiese riglyn wat ter sprake kom, is die belydenis in die Ou Testament dat die mens na die beeld van God geskep is.

In die skeppingsgedig van Genesis 1 word vertel dat die mens aan die einde van die skeppingsgebeure op 'n baie unieke manier deur God geskep is. Dit is asof God met homself in gesprek tree en sê:

Kom Ons maak die mens as ons verteenwoordiger, ons beeld, sodat hy kan heers oor die vis in die see, die voëls in die lug, die mak diere, die wilde diere en al die diere wat op die aarde kruip.

Wiersbe (1993:22) stel dit soos volg: "There is a "divine conference" among the members of the Godhead before man is created, something not seen at any other step of the Creation.'

Geen ander deel van die skepping word op so 'n wyse direk aan God verbind soos die mens nie. Slegs die mens word God se beeld genoem.

Die Hebreeuse woord wat hier gebruik word, is die woord selem. The complete word study dictionary: Old Testament (Baler 2003) verduidelik dit soos volg:

A masculine noun meaning an image, a likeness, a statue, a model, a drawing, a shadow. The word means image or likeness; its most celebrated theological and anthropological use was to depict human beings as made in God's own image (Gen 1:26, 27; 5:3). People continue to be in His image even after the fall, although the image is marred (Gen 9:6), and still serves as the basis of the prohibition not to kill human beings. (p. 6754)

Dit blyk dus dat die woord bedoel dat daar 'n noue ooreenkoms is tussen die werklikheid en die beeld wat 
gevorm of gemaak word. Die een verteenwoordig in baie realistiese terme die ander.

Dit is hoe oor die skepping van die mens gepraat word. Wat verder hier opvallend is, is die feit dat dit van die mens gesê word nog voor die sondeval. Lazenby (2013) stel dit soos volg:

Of die mens dus glo of nie, hy/sy leef as verteenwoordiger van God op aarde om namens God orde te handhaaf, kultuur te ontwikkel en God se skepping ten goede te dien. (bl. 107)

Wat vra hierdie wete van die mens? Wanneer Johannes aan die gemeente 'n pastorale brief skryf, beklemtoon hy die wese van God. Hy sê in 1 Johannes 1:5: 'God is lig en daar is geen duisternis in hom nie.' Later in 1 Johannes 4:8 en 16 skryf hy: 'God is liefde'. Dat God lig en liefde is, speel 'n belangrike rol in die Bybel om God se teenwoordigheid by sy volk te verseker. Wanneer God in die woestyn vir Moses roep om sy volk uit Egipte uit te lei, verskyn Hy aan hom in die vorm van 'n brandende bos (lig) in die woestyn. Later gedurende die volk se trek deur die woestyn op pad na die beloofde land, kry Aäron die opdrag om dwarsdeur die nag olielampe in die tent van samekoms te laat brand, sodat die lig wat skyn die volk gedurig daaraan kan herinner dat God in hulle midde teenwoordig is (Lev 24:2, 3). Die lamp in die tent van samekoms moes die volk Israel gedurig daaraan herinner dat God lig is. Van Zyl (1989:141) sê: ' ... die bedoeling van die olielampe wat dwarsdeur die nag moes brand, was klaarblyklik nie net om lig te gee nie, maar ook om as simbool te dien van die lig en lewe wat God gee'.

Wanneer hierdie uitspraak oor God in gedagte gehou word, verstaan ' $n$ mens skielik beter wat Jesus bedoel het toe Hy die skare in die bergpredikasie (Matt 5:13,16) geleer het deur te sê:

Julle is die lig vir die wêreld. Laat julle lig so voor die mense skyn, dat hulle julle goeie werke kan sien en julle Vader wat in die hemel is, verheerlik.

Die manier waarop die mens God op aarde moet verteenwoordig, is deur jou goeie dade - dade van gehoorsaamheid aan Hom. Die opdrag om God in jou dade te verteenwoordig, hou ook verband met die herhaaldelike opdrag in Levitikus $(11: 44,45 ; 19: 2 ; 20: 26)$ om heilig te wees soos wat God heilig is. Mense wat heilig leef, wys hoe heilig die God is wat hulle aanbid. Goeie dade se doel is nooit om die mens te verheerlik nie, maar om God daardeur te verheerlik. Deur die mens se goeie dade skyn God se heerlikheid in hierdie wêreld soos ' $n$ lig. Wanneer Johannes hieroor met die gemeente praat, sê hy verder in 1 Johannes 4:12: 'Niemand het God nog ooit gesien nie, maar as ons mekaar liefhet, bly God in ons en het sy liefde in ons sy doel volkome bereik.' Dit is asof Johannes vir die gemeente sê hulle moet God aan die wêreld sigbaar maak deur mekaar lief te hê en in liefde saam te leef. Wat 'n geweldige gedagte dat mense God op aarde sigbaar moet laat word!

$\mathrm{Al}$ is dit so dat die mens God op aarde verteenwoordig omdat dit deel van die mens se skeppingsmatigheid is, is dit ook waar dat die gelowige mens op ' $n$ baie spesiale manier God na die sondeval op die aarde verteenwoordig. Paulus skryf hieroor aan die gemeente in Korinte en sê in 1 Korintiërs 3:16:

Weet julle nie dat julle die tempel van God is en dat die Gees van God in julle woon nie? As iemand die tempel van God beskadig, sal God hom straf, want die tempel van God is heilig, en die tempel is julle.

Na die herskeppende werk van God in mense se lewens vorm hulle saam die plek waar God deur sy Heilige Gees kom woning maak het. Om hierdie saak verder te beklemtoon, sê Paulus in 1 Korintiërs 6:19 dieselfde van elke gelowige mens:

Of besef julle nie dat julle liggaam ' $n$ tempel van die Heilige Gees is nie? Julle het die Heilige Gees, wat in julle woon, van God ontvang, en julle behoort nie aan julleself nie: julle is gekoop, en die prys is betaal. Julle moet God dus in julle liggaam verheerlik.

Nie net die gemeente as geheel nie, maar elke gelowige mens is ook op 'n baie spesiale manier draer van die Heilige Gees. Waar gelowiges dus elke dag beweeg, praat, werk, ontspan of leef, is hulle verteenwoordigers van God as God se nuutgemaakte tempel.

Die eerste belangrike beginsel waarvan hier dus kennis geneem moet word, is die feit dat die mens in sy skeppingsmatigheid en die gelowige as herskepte eiendom van God, die verantwoordelikheid het om namens God op aarde op te tree. Lazenby (2013) noem:

Wat die mens dus ook al doen, mag nooit om die mens as sodanig gaan nie, maar altyd om die eer van God. Hierdie waarheid geld ook die gebruik van die Internet en ander kommunikasiemiddele. (bl. 108)

\section{God se liefdesgebod}

In aansluiting by wat hierbo gesê is, moet vervolgens aandag gee word aan die stel norme wat God vir die mens neerlê sodat die mens tot sy eer kan leef en tegelyk 'n missionale verskil in hierdie wêreld maak.

Toe Israel deur die woestyn getrek het op pad na die beloofde land, het God aan hulle 'n stel reëls gegee waarvolgens Hy verwag het dat hulle sal lewe ten einde as sy verbondsvolk uit te staan tussen die ander volkere rondom hulle. Hierdie stel reëls staan allerweë bekend as die Tien Gebooie of die Wet van God. Dit is op twee plekke in die Ou Testament volledig opgeteken, naamlik in Eksodus 20 en Deuteronomium 5. Met 'n eerste oogopslag lyk dit dus of dit by God gaan om die nakoming van 'n klompie reëls en regulasies indien die mens tot sy eer wil leef. Die fariseërs en Skrifgeleerdes het later ook sodanig geredeneer en om seker te maak dat hulle die wil van die Here ten volle doen, het hulle die tien gebooie wat God gegee het nog verder uitgerafel en daarby nog 346 reëls geformuleer. So het hulle die volk onderrig met die uitgangspunt dat dit in die mens se verhouding met God gaan om die nakoming van reëls sodat God tevredegestel kan word. 
Die probleem wat die Joodse leiers van Jesus se tyd gehad het, word kripties in die woorde van Matteus 23:23-25 saamgevat:

Julle gee tiendes van kruisement, anys en koljander, maar wat volgens die wet van God die swaarste weeg, laat julle na: geregtigheid, barmhartigheid en betroubaarheid. Juis hierdie dinge moet ' $n$ mens doen en die ander nie nalaat nie. Blinde leiers! Julle skep die muggie uit julle beker uit, maar julle sluk die kameel in. Julle maak die buitekant van die beker en die skottel skoon, maar binne is hulle vol hebsug en onmatigheid.

Hiermee het Jesus beklemtoon dat dit in ons verhouding met God nie gaan om die blote uiterlike nakoming van allerlei wette en reëls nie, maar wel in die eerste instansie om ' $n$ innerlike gesindheid wat in die uiterlike manier van lewe sigbaar moet word. Hierdie innerlike gesindheid word in die Bybel saamgevat in een woord, naamlik liefde. Die gerigtheid van hierdie liefde lê op 'n vertikale asook 'n horisontale vlak. Die vertikale vlak kom na vore in die woorde: 'Luister, Israel, die Here is ons God, Hy is die enigste Here. Daarom moet jy die Here jou God liefhê met hart en siel, met al jou krag' (Deut 6:4 en 5; vgl. ook Matt 22:37; Mark 12:30), terwyl die horisontale vlak blyk uit: '... jy moet jou naaste liefhê soos jouself' (Lev 19:18; vgl. ook Matt 22:39; Mark 12:31).

Wat Jesus dus doen, is om die mens daarop te wys dat gesonde etiek waardeur God verheerlik word, nie op die blote nakoming van ' $n$ klomp uiterlike regulasies gebou is nie, maar dat dit veral uit gedrag bestaan wat onder leiding van die Heilige Gees uit die binneste van die mens gemotiveer word deur 'n gesindheid van opregte liefde. Opregte liefde het ten doel om God en ander mense se eer na te jaag. Die probleem van die Skrifgeleerdes en fariseërs wat Jesus in Matteus 23 aangeroer het, was juis in 'n lewenswyse geleë wat uitsluitlik op die eie eer gerig was, dikwels ten koste van ander. Opregte liefde bring juis mee dat die eie ek van die mens verdwyn en dat jou optrede nooit ten koste van ander geskied nie. Hierdie gesindheid word verder beklemtoon deur teksgedeeltes soos 1 Korintiërs 13 en Kolossense 3:8-9, 13-17.

\section{Gevolgtrekking}

Omdat die wesenlike doel van God met sy kerk op aarde verband hou met die vestiging van God se koninkryk oor die hele wêreld, vorm die missionale opdrag aan sy kerk die belangrikste motivering en dryfkrag agter die doel van gelowiges se daaglikse lewe waar hulle ook al mag beweeg. Om hierdie missionale roeping gehoorsaam uit te leef, moet die mens in sy kommunikasie met ander, deur die benutting van die sosiale media, aan die beginsels in God se Woord voldoen. Hiermee word nie bedoel dat die gelowige tydig en ontydig die evangelie moet verkondig nie, maar dat die beginsels van die bybelse etiek soos dit in hierdie artikel uitgespel is, in elke gesprek gehoorsaam sal word. Die praktiese implikasie is dat beginsels soos bedagsaamheid, respek vir ander, eerlikheid, vriendelikheid en opbouende taal, gebruik sal word om die gesindheid van Jesus oor te dra. Die riglyne vir die nuwe lewe wat Paulus in Efesiërs 4:25-31 uitspel, is hier van toepassing. Hierdeur sal ruimte geskep word vir die openbaring van die vrug van die Gees (Gal 5:22-26) deur die netwerk van die sosiale media. Wanneer die geleentheid tot spontane getuienis oor die evangelie hom voordoen, moet dit benut word om God se liefde aan die wêreld te verkondig.

\section{Erkenning Mededingende belange}

C.N. (Universiteit Pretoria) was die projek toesighouer en verantwoordelik vir die ontwerp van die projek en die konseptuele bydrae. M.L. (Universiteit Pretoria) was verantwoordelik vir die navorsing, uitvoering en finalisering van die projek. M.L. het ook konseptuele bydraes gelewer en het meeste van die literatuur navorsing gedoen.

\section{Outeursbydrae}

Die outeurs verklaar dat hulle geen finansiële of persoonlike verbintenis het met enige party wat hulle nadelig kon beïnvloed het in die skryf van hierdie artikel nie.

\section{Literatuurverwysings}

Baker, W., 2003, The complete word study dictionary: Old Testament, AMG Publishers, Chattanooga.

Bosch, D.J., 1991, Transforming mission, Orbis Books, New York.

Brown, M., 2011, Learn to use Facebook, Twitter, and Linkedln: The how-to guide, viewed 06 March 2014, from Amazon.com (Kindle edn.).

Challies, T., 2011, The next story: Life and faith after the digital explosion, viewed 08 June 2012, from Amazon.com (Kindle edn.).

Christian Medical Fellowship, 2012, Christian Medical Fellowship, viewed 08 March 2012, from http://www.cmf.org.uk/publications/content.asp?context=article\&id=1330

Claassens, G. \& Loubser, G., 2010, Die Bybel en sy boodskap: Kursus vir lidmate, module 1, Sentrum vir Kontekstuele Bediening, Universiteit van Pretoria, Pretoria.

Deckers, E. \& Lacy, K., 2010, Branding yourself: How to use social media to invent or reinvent yourself (Que Biz-Tech), viewed 08 June 2012, from Amazon.com (Kindle edn.).

Feinberg, J.S. \& Feinberg, P.D., 2010, Ethics for a brave new world, 2nd edn, viewed 16 March 2012, from Amazon.com (Kindle edn.).

Geisler, N.L., 2010, Christian ethics: Contemporary issues \& options, 2nd edn., viewed 15 March 2012, from Amazon.com (Kindle edn.).

Hille, O., 2011, Social media - For income, influence and impact - Turn your passions into income - Online! (Make money via social networking, Facebook, Twitter, YouTube, Internet marketing, and web marketing), viewed 10 March 2014, from Amazon.com (Kindle edn.).

Kaplan, A.M. \& Haenlein, M., 2010, Users of the world, unite! The challenges and opportunities of social media, Business Horizons, New Delhi.

Kok, J., 2011, 'Mission and ethics in Galatians', HTS Teologiese Studies/Theological Studies 67(1), Art.\#896, 10 pages.

Lazenby, M.J., 2013, 'Missionale kerk-wees en die benutting van die internet in die plaaslike gemeente met spesifieke verwysing na die webblad', DD-proefskrif, Fakulteit Teologie, Universiteit van Pretoria.

Leffel, J., 2012, Christian witness in a pluralistic age, viewed 23 February 2013, from http:// www.xenos.org/essays/ pluralsm.htm

M86-Security Labs, 2012, Threat statistics, viewed 08 March 2012, from http://www. m86security.com/labs/spam_statistics.asp

Nederduitse Gereformeerde Kerk, Algemene Sinode/Sinodale Kommissie, 1988, Handboek vir die erediens, Nasionale Boekdrukkery, Goodwood.

NGK, kyk Nederduitse Gereformeerde Kerk.

Rice, J., 2009, The church of Facebook: How the hyperconnected are redefining community, viewed 10 March 2014, from Amazon.com (Kindle edn.).

Saayman, W., 2007, Being missionary - Being human: An overview of Dutch Reformed mission, Cluster Publications, Pietermaritzburg.

Spamhaus, 2012, The world's worst spam producing countries, viewed 08 March 2012, from http://www.spamhaus org/statistics/countries.lasso

Spamlaws, 2012, Spam statistics and facts, viewed 08 March 2012, from http://www. spamlaws. com/spam-stats.html

Stanley, C.F., 2011, Turning the tide: Real hope, real change, Howard Books, New York.

Turner, A., 2012, Developing a set of biblical ethics, viewed 08 March 2012, from http:// allanturner.com/ethic.html

Van Zyl, A.H., (Hoofred.), 1989, Verklarende Bybel (1983-vertaling), Lux Verbi, Kaapstad.

Wiersbe, W.W., 1993, Wiersbe's expository outlines on the Old Testament, Victor Books, Wheaton.

Wright, C.J.H., 2006, The mission of God, InterVarsity, Westmont.

Wright, C.J.H., 2010, The mission of God's people, viewed 20 May 2011, from Amazon.com (Kindle edn.).

Wright, N.T., 2012, How God became King: The forgotten story of the Gospels, viewed 12 March 2012, from HarperCollins.com (EPub edn.). 